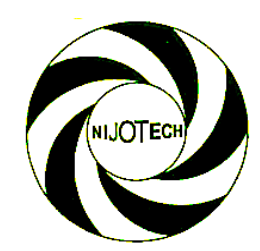

Nigerian Journal of Technology (NIJOTECH)

Vol. 37, No. 4, October 2018, pp. 1026 - 1031

Copyright(C) Faculty of Engineering, University of Nigeria, Nsukka

Print ISSN: 0331-8443, Electronic ISSN: 2467-8821 www.nijotech.com

http://dx.doi.org/10.4314/njt.v37i4.23

\title{
PYROLYTIC ANALYSIS OF COCOA POD FOR BIOFUEL PRODUCTION
}

\author{
A. 0. Akinola ${ }^{1,}{ }^{*}$, J. F. Eiche ${ }^{2}$, P. 0. Owolabi ${ }^{3}$ and A. P. Elegbeleye ${ }^{4}$ \\ 1, 2, 3, 4, Mechanical EngineERING DePt., Federal University of TeChNology AKURE, ONDo State, NigERIA \\ E-mail addresses:1 akinteche@yahoo.com, 2 arcfessy@gmail.com,3femspok@yahoo.com, \\ 4 ayokunleism@yahoo.com
}

\begin{abstract}
This study carried out pyrolytic conversion of cocoa pod husk in a refurbished fixed bed type 17.4 litres capacity electric thermal reactor. The process was studied by heating $1 \mathrm{~kg}$ of dried sample at an average size of $20 \mathrm{~mm} \times 30$ $\mathrm{mm} \times 1.9 \mathrm{~mm}$ and moisture content of $13.78 \%$ at four different temperatures $\left(300^{\circ} \mathrm{C}, 400^{\circ} \mathrm{C}, 500^{\circ} \mathrm{C}\right.$ and $\left.600^{\circ} \mathrm{C}\right)$ using two electrical heating coils of $2.5 \mathrm{~kW}$ each. Bio-oil and bio-gas were produced and characterized. The average heating values of bio-oil and bio-gas were $36.23 \mathrm{MJ} / \mathrm{kg}$ and $35.24 \mathrm{MJ} / \mathrm{kg}$ respectively. These were higher to that obtainable from other fuels like Coal (27 MJ/kg) and Ethanol (29.7 MJ/kg). Physiochemical properties of bio-oil gave an average value of $0.9543 \mathrm{~g} / \mathrm{m}^{3}$ for density, and $1.88 \mathrm{~mm}^{2} / \mathrm{s}$ for viscosity. The density is similar to that of diesel fuel $(0.83 \mathrm{~g} / \mathrm{ml})$ but lower in viscosity $\left(3.10 \mathrm{~mm}^{2} / \mathrm{s}\right)$. Gas chromatography analysis of bio-gas shows that $\mathrm{CO}_{2}, \mathrm{CO}_{1} \mathrm{CH}_{4}, \mathrm{H}_{2} \mathrm{~S}$ and $\mathrm{H}_{2} \mathrm{O}$ contents increased with increase in pyrolysis temperature. From the ultimate analyses carried out, the pyrolysis process produced bio-oil with an average of $75 \%$ carbon composition, $6.61 \%$ hydrogen, $7.11 \%$ oxygen, $0.16 \%$ nitrogen and $0.007 \%$ sulphur. The proximate analysis showed bio-oil has an average of $25.57 \%$ volatile matter and $58.44 \%$ fixed carbon. Results showed that pyrolysis is an efficient and sustainable means of converting cocoa pod husk into rich sources of useful biofuel.
\end{abstract}

Keywords: pyrolysis, fixed-bed reactor, proximate analysis, ultimate analysis, volatile matter.

\section{INTRODUCTION}

The problems that are associated with the use of fossil fuel demand a transition to renewable sources for energy. The methods of extracting crude oil have also led to serious cases of oil spills which tend to destroy the immediate or remote environment where such resources are found. The impact of the high price of fossil fuels on the economic growth of many developing countries has been severe and the growing demand for energy associated with economic growth has emphasized the need to develop alternative energy. Pyrolysis is a chemical reaction that involves breakdown of larger molecules into smaller molecules using heat, but in the absence of oxygen. Pyrolysis is a promising thermal approach that can be used to convert biomass into energy in the form of bio-oil, biochar and bio-gas [1].

Biomass such as forest residues and agricultural crops can under certain conditions, provide a viable renewable source for electricity generation and heat. It can supply local communities close to production areas or offer products (biodiesel, biogas) that can replace some of the current fuels used for heating and transportation [2]. Among the different biomass agricultural waste residues, cocoa pod is an abundant source of biomass very much available in Nigeria with vast quantities of sugars occurring structural polysaccharide- cellulose and hemicelluloses. It is estimated that 0.8 to 1.0 million tons of cocoa pod husk $(\mathrm{CPH})$ is generated annually in cocoa farms in Nigeria, hence representing one of the most important Nigerian agricultural residues [3].

According to [4], the proximate compositions of five agricultural wastes were determined and later subjected to low temperature pyrolysis process in the presence of nitrogen atmosphere. These wastes are Cocoa nucifera husk; Theobroma cacao pod (CPH), Kola nitida pods and plantago major peels (ripe and unripe peels). All the samples investigated have different intrinsic proximate compositions which affect the yields of their respective chars. The potential to convert lignocellulosic material like cocoa pod into biochar and bio-oil is generating renewed interest in pyrolysis [5].

According to [6], three chemical activation agents $\left(\mathrm{K}_{2} \mathrm{CO}_{3}, \mathrm{KOH}\right.$ and $\left.\mathrm{ZnCl}_{2}\right)$ to obtain activated carbons 
from cocoa pod husk and then characterized it using Brunaver-Emmett-Teller (BET). The results obtained revealed that cocoa pod husk is a material that can be used to produce activated carbon by chemical activation and $\mathrm{ZnCl}_{2}$ showed to be the best chemical activation agent based on the highest BET surface area $\left(780 \mathrm{~m}^{2} / \mathrm{g}\right.$ in the best case) and pore volume $(0.58$ $\mathrm{m}^{3} / \mathrm{g}$ in the best case), the lowest ash content $(6.14 \%$ in the best case), and the highest carbon content ( $86.1 \%$ in the best case), compared to other chemicals.

In their work, [7] designed a charcoal fired reactor for small-scale production of biochar. The method of biochar production offered by this equipment was evaluated by comparing its output with a single barrel method of production. The results obtained during the test indicated that the efficiency of the equipment based on its output per kg of Cocoa pod husk was $79.9 \%$ and also revealed that cocoa pod husk could be effectively used as raw material for biochar production. Pretreatment of cocoa pod husk with acid and alkaline to increase the potential of bio-gas production by anaerobic digestion was carried out by [8]. The results obtained showed that $\mathrm{CPH}$ has Lignocellulosic substrate potential for production of biogas.

Various research has been carried out on pyrolysis of cocoa pod husk, with large percentage of the studies focused on reactor design, product characterization and quality improvement without considering the viability of generating bio-fuels using pyrolysis at varying temperature. In view of this, this work aims to ascertain the viability of generating bio-fuels from cocoa pod husks by using pyrolysis at varying temperatures to produce two fractions of bio-fuels (bio-oil and bio-gas). The two produce are then characterized.

\section{MATERIALS AND METHODS}

\subsection{Material}

Cocoa Pod Husk was collected from cocoa plantations at Idanre Local Government Area of Ondo State, Nigeria.

\subsection{Apparatus and Equipment}

The apparatus and equipment used for this research are as follows;

\subsubsection{Thermal Reactor}

The pyrolysis process was carried out using an existing batch process fixed bed reactor designed and tested for pyrolysis using wood [9]. It consists of heating chamber where the pyrolysis of cocoa pod husk was carried out. It has a 17.4 litre capacity built with clay as its refractory material and encased in a steel frame work. It was equipped with a temperature controller and thermocouple for varying and measuring the temperature within the chamber. The reactor was refurbished to improve its performance and output through reinforcement with cement to block all leakages, and heat gaskets replaced. The discharge pipes were replaced and the inner surface of the furnace was lined with two heating elements of $2.5 \mathrm{~kW}$ each.

\subsubsection{Condensing Unit}

This is the heat exchanger where volatiles generated from the heating chamber are cooled in order to capture the condensable liquid (Bio-oil). It consists of a water reservoir, connecting hoses and a water pump for increasing the water flow rate so as to increase the cooling rate of the condenser.

\subsubsection{Bio-oil Collector, Bio-Gas Cylinder, Weighing balance and Vacuum Pump}

The bio-oil collector is a transparent glass used for the collection of the bio oil produced during the pyrolysis process. It is attached to the exit pipe of the condensing unit which passes through an air tight rubber cork used as its cover. Bio-gas cylinder was used to collect the non-condensable gas (bio-gas) produced from the pyrolysis of the cocoa pod husk. It is made up of a locally sourced refrigerant cylinder. It has a resistance to heat and equipped with a pressure valve to avoid leakages. It is connected to the gas pipe with aid of manifold hose. Digital top weighing balance with weighing scale accuracy of $0.001 \mathrm{~g}$ was used to measure the mass of the samples before and after pyrolysis. XZ-1B Vacuum pump was used to evacuate air and moisture from the gas collectors before each experiment for easy flow of the bio gas. It was equipped with manifold gauges and hose.

\subsection{Cocoa Pod Sample Characterization}

The dried cocoa pod sample was characterized before pyrolysis. Proximate analysis was carried out and its moisture content, volatile matter, fixed carbon content and ash were determined using ASTM D3174-76. Ultimate analyses were carried out using same standard where its constituent element like carbon, hydrogen, Nitrogen, Sulphur and Oxygen were determined. Heating value was determined using a Gallenkamp Ballistic Bomb Calorimeter. 


\subsection{Experimental Procedures}

Cocoa Pod Husk was pyrolysed into bio fuels using a 17.4 litre capacity thermal reactor under atmospheric pressure at an average heating rate of $0.09{ }^{\circ} \mathrm{C} / \mathrm{s}$. It was equipped with a condensing unit, water tank, water pump, thermocouple, temperature controllers, bio-oil and biogas collectors. The pyrolysis was conducted at four different temperatures; $300^{\circ} \mathrm{C}, 400^{\circ} \mathrm{C}, 500^{\circ} \mathrm{C}$ and $600^{\circ} \mathrm{C}$. Cocoa pod husk sample was collected and sun dried for 7 days as shown in Plate 1.

Its moisture content was determined from result of the proximate analysis test. The dried sample was crushed to an average size of $20 \mathrm{~cm} \mathrm{x} 30 \mathrm{~cm}$. The dried pods were divided into four groups of $1 \mathrm{~kg}$ each, labeled A, B, C and D.

Sample A was fed into the reactor at room temperature of $25^{\circ} \mathrm{C}$ and heated to a temperature of $300^{\circ} \mathrm{C}$. The volatiles coming from the heating chamber passed through water cooled condenser. After undergoing rapid cooling, the condensable fraction of the volatile known as bio-oil was collected in an air tight transparent beaker dipped in an ice bath, while the non- condensable fraction known as bio-gas was collected in a vacuumed gas cylinder. The yields for each sample were determined by mass of each product and expressed as a percentage. When the set temperature was attained, the residence time for the pyrolysis process was determined when no significant products (bio-oil and bio-gas) was observed. These same procedures were applied to pyrolyse samples at temperatures of $400^{\circ} \mathrm{C}, 500^{\circ} \mathrm{C}$ and $600^{\circ} \mathrm{C}$ respectively. The procedures carried out on sample A were repeated for samples B, C and D at the varying temperatures respectively, on three experimental runs for each sample. Average values of the readings were taken. The sample before pyrolysis and produced bio-fuels after pyrolysis at the different temperatures were characterized by determining the ultimate, proximate and energy content using GC/MS gas chromatography Thermal Conductivity detector (TCD) and a flame Ionization Detector (FID). The schematic diagram of pyrolysis unit is shown in Figure 1 according to [9].
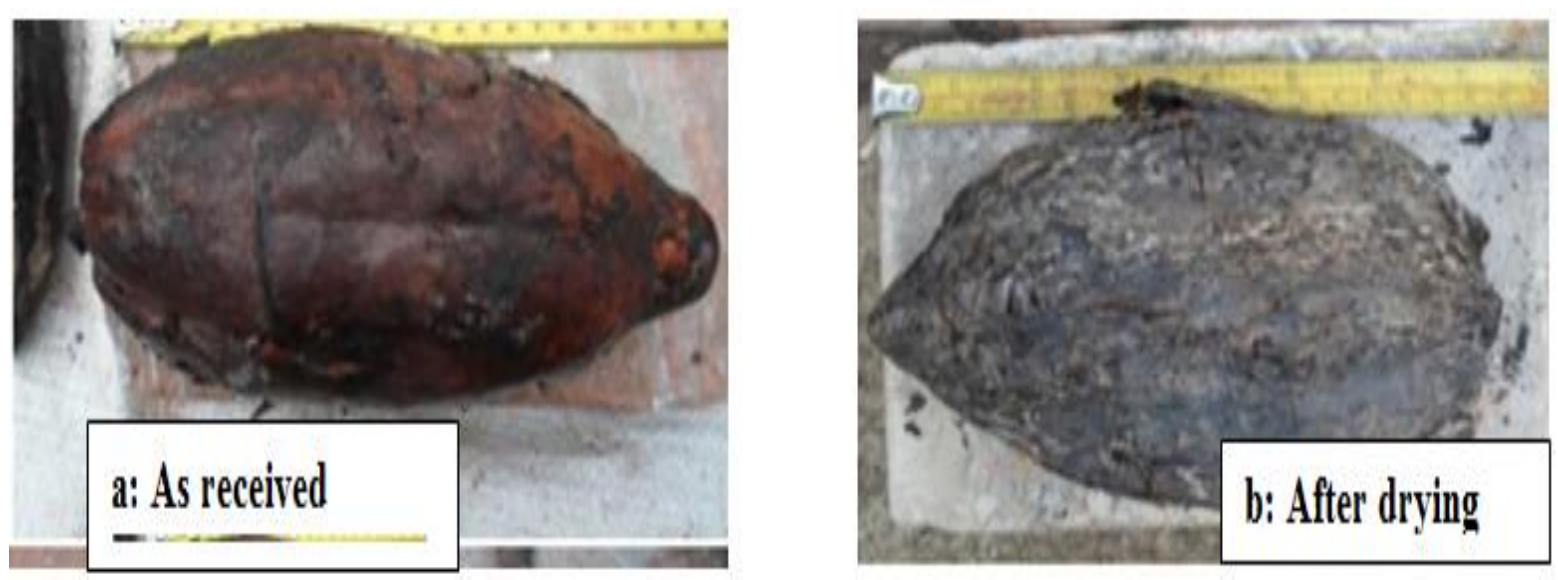

Plate 1: Cocoa pod husks (a) as received, (b) one week after drying

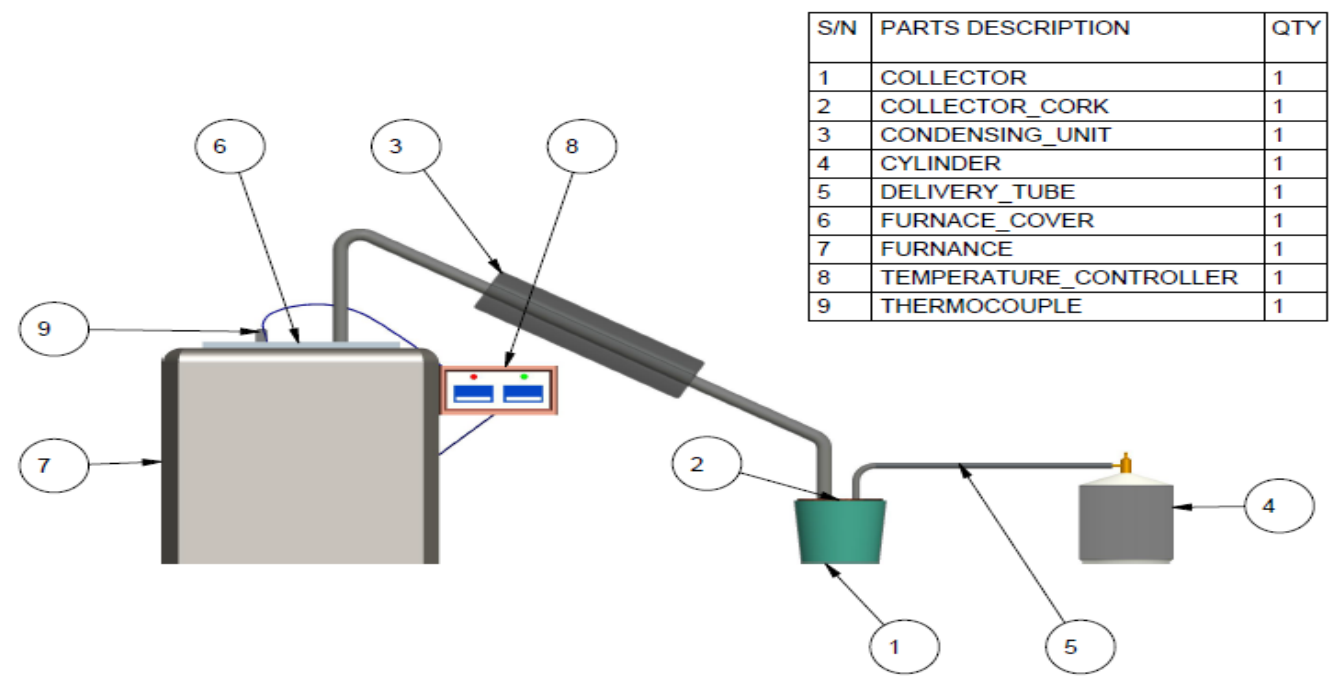

Figure 1: Schematic diagram of pyrolysis unit 


\section{RESULT AND DISCUSSION}

\subsection{Feedstock Characterization}

Physical and elemental analyses of the feedstock, Cocoa Pod Husk (CPH), used for this experiment are presented in Table 1 . The raw material moisture content affects not only the performance of the solid biofuels on thermochemical processes, but also the phenomena occurring during densification. The higher the moisture content the more energy is wasted when using the raw material on thermochemical processes. The moisture content of the $\mathrm{CPH}$ was $14.43 \%$. The higher the volatile matter in the raw material, the faster this biofuel will ignite. The volatile matter content of CPH was $58.75 \%$, which is about $24 \%$ higher than that of coal (34.8\%). Fixed carbon is the most valuable parameter in terms of energy potential; raw material with higher fixed carbon has higher heating values. Fixed carbon of $\mathrm{CPH}$ was $19.83 \%$, which is lower than that of coal (56\%) but higher than wood (15\%). This agrees with the results presented by [10]. The heating value was $18.87 \mathrm{MJ} / \mathrm{kg}$. [9; 11]

\subsection{Products Characterization}

\subsubsection{Bio-oil Characterization}

The results of the collected bio oil at the four different temperatures for ultimate analysis, proximate analysis and physical properties are presented in Tables 2, 3 and 4 respectively. Elemental analysis showed that percentage of carbon increased with increase in temperature, while hydrogen, oxygen, nitrogen and carbon dioxide decreased with increase in temperature. The moisture content of the bio-oil dropped from $18.94 \%$ to $13.84 \%$ as the pyrolysis temperature increased from $300^{\circ} \mathrm{C}$ to $600^{\circ} \mathrm{C}$ respectively. There is little variation in the physical properties with the increase in temperature. The viscosity of the bio-oil increased from 1.79 to 1.97 $\mathrm{mm}^{2} / \mathrm{s}$ with increase in temperature. This is comparatively higher than the viscosities of gasoline $\left(0.67 \mathrm{~mm}^{2} / \mathrm{s}\right)$ but less than diesel $\left(2.1 \mathrm{~mm}^{2} / \mathrm{s}\right)[12 ; 13]$. The heating value of bio-oil obtained from this experiment ranges between 34.21 to $37.69 \mathrm{~kJ} / \mathrm{kg}$ from 300 to $600^{\circ} \mathrm{C}$ pyrolysis temperature. This gives an average heating value of $36.23 \mathrm{MJ} / \mathrm{kg}$ at an average temperature of $450^{\circ} \mathrm{C}$. This is equivalent to $10.06 \mathrm{kWh}$ of electricity, a value higher than that of wood (6.06 $\mathrm{kWh})$, but lower than gasoline (13.14 kWh) and diesel (12.44 kWh) respectively [9; 14].

\subsubsection{Bio-gas characterization}

The trapped gas products at varying pyrolysis temperature were taken for gas chromatography analysis. Table 4 shows how bio-gas composition varied with pyrolysis temperature. Similar trends were reported by [15], where the increase was explained by oxidation of the carbonized bio-char at higher temperature of pyrolysis.

The heating values of the bio-gas at different pyrolysis temperature were analyzed based on the standard heating values from combustion of common fuel gases. The heating values increased as pyrolysis temperature increased from $300^{\circ} \mathrm{C}$ at $34.58 \mathrm{MJ} / \mathrm{kg}$ to $600^{\circ} \mathrm{C}$ at 36.17 $\mathrm{MJ} / \mathrm{kg}$ as shown in Figure 2, and its comparison with other fuels is depicted in Figure 3.

Table 1: Proximate and Ultimate Analyses of Raw CPH used for pyrolysis

\begin{tabular}{cccc}
\hline & ULTIMATE & & PROXIMATE \\
\hline Parameters & Value (\%) & Parameters & Value (\%) \\
\hline Carbon & 48.82 & Moisture & 14.43 \\
Hydrogen & 7.89 & Volatile matter & 58.75 \\
Oxygen & 39.85 & Fixed Carbon & 19.83 \\
Nitrogen & 1.95 & Ash & 6.99 \\
Surphur & 1.49 & & \\
\hline
\end{tabular}

Table 2: Proximate analysis of bio-oil Samples

\begin{tabular}{cccccc}
\hline SAMPLE & \%MOISTURE & \%VM & \%ASH & \%FC & HHV (kJ/kg) \\
\hline $300^{\circ} \mathrm{C}$ & 18.94 & 23.92 & 0.28 & 56.86 & 34.21 \\
$400^{\circ} \mathrm{C}$ & 15.73 & 25.51 & 0.15 & 58.61 & 36.15 \\
$500^{\circ} \mathrm{C}$ & 14.87 & 26.07 & 0.09 & 58.97 & 36.88 \\
$600^{\circ} \mathrm{C}$ & 13.84 & 26.78 & 0.05 & 59.33 & 37.69 \\
\hline
\end{tabular}


Table 3: Ultimate analysis of bio-oil samples

\begin{tabular}{cccccccc}
\hline SAMPLE & $\% \mathrm{C}$ & $\% \mathrm{H}$ & $\% \mathrm{O}$ & $\% \mathrm{~N}$ & $\% \mathrm{CO}_{2}$ & $\% \mathrm{~S}$ \\
\hline $300^{\circ} \mathrm{C}$ & 67.68 & 7.93 & 11.46 & 0.25 & 12.67 & 11.41 & 0.009 \\
$400^{\circ} \mathrm{C}$ & 74.85 & 6.68 & 6.88 & 0.17 & 0.14 & 10.46 & 0.007 \\
$500^{\circ} \mathrm{C}$ & 77.78 & 6.14 & 5.47 & 0.08 & 9.77 & 0.002 \\
$600^{\circ} \mathrm{C}$ & 79.68 & 5.69 & 4.62 & 0.77 \\
\hline
\end{tabular}

Table 4: Physiochemical Properties of CPH Bio-oil

\begin{tabular}{|c|c|c|c|}
\hline SAMPLE & DENSITY $\left(\mathrm{g} / \mathrm{ml}^{3}\right)$ & $\mathrm{pH}$ & VISCOSITY $\left(\mathrm{mm}^{2} / \mathrm{s}\right)$ \\
\hline $300^{\circ} \mathrm{C}$ & 0.9528 & 4.86 & 1.79 \\
\hline $400^{\circ} \mathrm{C}$ & 0.9539 & 4.94 & 1.85 \\
\hline $500^{\circ} \mathrm{C}$ & 0.9548 & 5.11 & 1.89 \\
\hline $600^{\circ} \mathrm{C}$ & 0.9557 & 5.18 & 1.97 \\
\hline
\end{tabular}

Table 5: Bio-Gas composition as a function of pyrolysis temperature

\begin{tabular}{cccccc}
\hline SAMPLE & $\% \mathrm{CO}_{2}$ & $\% \mathrm{H}_{2} \mathrm{~S}$ & $\% \mathrm{CO}$ & $\% \mathrm{CH}_{4}$ & $\% \mathrm{H}_{2} \mathrm{O}$ \\
\hline $300^{\circ} \mathrm{C}$ & 23.89 & 1.07 & 0.68 & 61.97 & 2.35 \\
$400^{\circ} \mathrm{C}$ & 26.84 & 1.13 & 0.73 & 62.35 & 2.54 \\
$500^{\circ} \mathrm{C}$ & 28.56 & 1.25 & 0.78 & 63.41 & 2.61 \\
$600^{\circ} \mathrm{C}$ & 30.26 & 1.31 & 0.84 & 64.75 & 2.73 \\
\hline
\end{tabular}

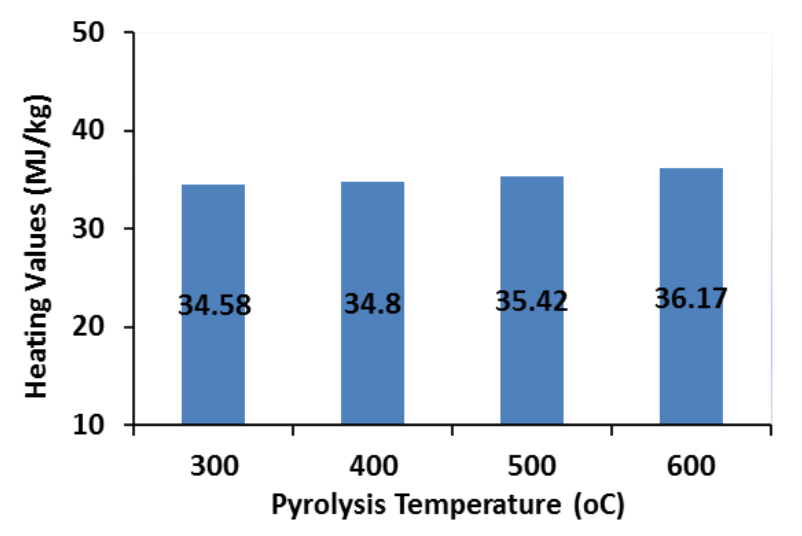

Figure 2: Heating values of CPH Bio-Gas as a function of pyrolysis

This is due to compositional variations of bio-gas components as shown in Table 5. Figure 3, which compares the Heating value of bio-gas with other fuel products, shows that the average heating value of biogas $(35.24 \mathrm{MJ} / \mathrm{kg})$ is greater than that of coal $(27$ $\mathrm{MJ} / \mathrm{kg}$ ) and Ethanol $(29.7 \mathrm{MJ} / \mathrm{kg})$ but significantly lower than natural gas $(52.2 \mathrm{MJ} / \mathrm{kg})$, gasoline $(47.3$ $\mathrm{MJ} / \mathrm{kg}$ ) and diesel $(44.8 \mathrm{MJ} / \mathrm{kg}$ ) which agrees with the findings of [16].

\section{CONCLUSION}

Cocoa Pod Husk (CPH) was pyrolysed at varying temperatures of $300^{\circ} \mathrm{C}, 400^{\circ} \mathrm{C}, 500^{\circ} \mathrm{C}$ and $600^{\circ} \mathrm{C}$ for energy fuels. The raw sample has a heating value of $18.87 \mathrm{MJ} / \mathrm{kg}$ compared to average values of the products; bio-oil (36.23 MJ/kg) and bio-gas (35.24

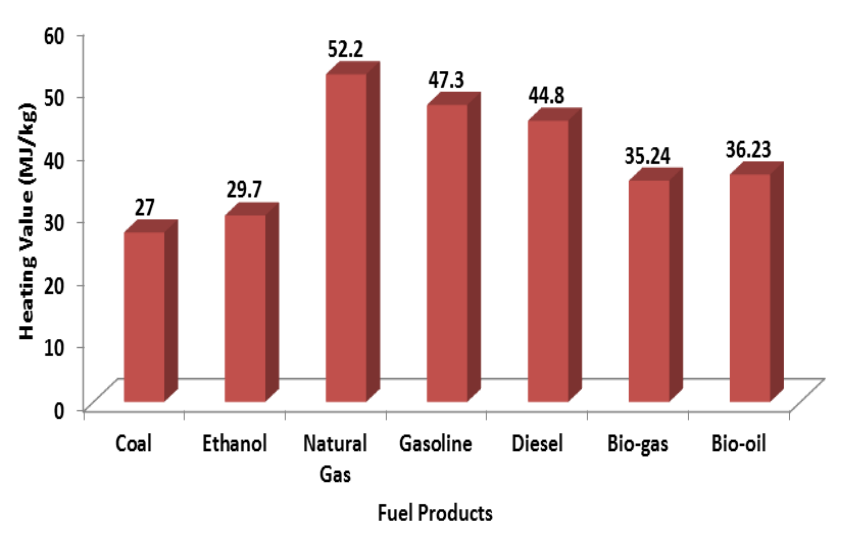

Figure 3: Heating Values of bio-gas and bio-oil compared to other fuel products

$\mathrm{MJ} / \mathrm{kg}$ ). Products characterization showed that the products contained negligible amount of Sulphur and Nitrogen which resulted in lower emission of $\mathrm{SO}_{2}$ and $\mathrm{NO}_{\mathrm{x}}$ than do conventional fossil fuels. The energy content of bio-oil is higher compared to bio-gas because of higher percentage of carbon and hydrogen based on elemental or ultimate analysis. With a heating values of $35.24 \mathrm{MJ} / \mathrm{kg}(9.79 \mathrm{kWh})$ for the bio-gas and $36.23 \mathrm{MJ} / \mathrm{kg}$ (10.06 kWh) for the bio-oil obtained, they could be burnt directly for heating or used as fuel for gas engines and gas turbines for electricity.

\section{ACKOWLEDGEMENT}

The authors acknowledge the efforts of Engr. Tech. Abiodun Adewole during the pyrolysis operations. He 
was very instrumental to the fixing of the thermal reactor during refurbishment.

\section{REFERENCES}

[1] Montenegro Y. S., Bensaid1 S., Ruggeri1 B., Restuccia L., Ferro G., Mancini G. Fino D., Valorisation of by-Products/Waste of Agro-Food Industry by the Pyrolysis Process. Journal of Advanced Catalysis Science and Technology, 3, 11, 1, 2016.

[2] Duke, M., Gu, S. and Hagen, E.: A Comprehensive Review of Biomass Resources and Biofuels Potential in Ghana. Renewble Sustainable Energy Review. vol. 15, pp. 404-415, 2011.

[3] Igbinadolor, R. Fermentation of Cocoa Pod Husk (Theobrama Cacao) and its Hydrolysate for Ethanol production using improved starter culture. PhD Thesis University of Ibadan, Ibadan, Nigeria, 2012.

[4] Adeyi, 0.: Proximate Composition of some Agricultural Wastes in Nigeria and their Potential use in Activated Carbon Production. Journal of Environmental Science and Management. vol. 14, pp. 55-58, 2010.

[5] Mason, L., Gustafson, R., Calhaun, J., Lippke B. and Raffaeli, N.: Wood to Energy in Washington. The college of forest Resources, University of Washington. Report to the Washington State Legislature, 2009.

[6] Cruz G., Pirila M., Huuhtanen M., Carrion L., Alvarenga E. and Keiski L. R.: Production of Activated Carbon from Cocoa Pod Husk. Journal of Civil and Environmental Engineering. 2:2. 2012.

[7] Odesola I. F. and Owoseni T. A.: Development of Local Technology for a Small-Scale Biochar Production Processes from Agricultural Wastes. Journal of Emerging Trends in Engineering and Applied Sciences (JETEAS) 1 (2): 205-208, 2016.
[8] Ward-Doria M., Arzuaga-Garrido J., Ojeda K. A., and Sanchez E. Production of Biogas from Acid and Alkaline Pretreated Cocoa Pod Husk. International Journal of Chem Tech Research. Vol. 9, pp. 252-260, 2016.

[9] Akinola A. 0.: Design of Thermochemical reactor for conversion of selected wood Biomass to fuel a stationary Diesel engine. An unpublished PhD Thesis at the Federal University of Technology; Akure, Nigeria. 2012.

[10] Akinola, A. O. and Fapetu, O. P.: "Characteristics Study of Wood Wastes from Sawmills" British Journal of Applied Science \& Technology 6(6): 606-612, 2015, 2015.

[11] Chelgani, S. C., Hower, J. C., Jorjani, E., Mesroghli, Sh. and Bagherieh, A. H.: Prediction of coal grindability based on petrography, proximate and ultimate analysis using multiple regression and artificial neural network models Fuel Processing Technology, 8913 - 20, 2008.

[12] ASME Y14.5 - 2009: Standard Kinematic Viscosity Table Chart of Liquids. Available at https://www.engineeresedge.com (accessed $18^{\text {th }}$ July, 2018)

[13] American Society for Testing and Materials (ASTM); "ASTM - D975-18 (Standard Specification for Diesel Fuel Oils). 2010.

[14] Huhtinen, M.: "Wood Energy: Wood as a Fuel" Materials for 5EURES Training Sessions; NCP, Finland. pp 1-4, 2009.

[15] Baker, S., Coburn, C. and Liu, C.: Combustion Properties of Biomass Flash Pyrolysis. Journal of Analytical and Applied Pyrolys, Vol. 74, pp. 71180, 2005.

[16] Murphy, W. and Masters, K.: Gross Heat of Combustion of Northern Red Oak (Quercusrubra) Chemical Components. Wood Science, Vol. 10, pp 139 - 141, 1998. 